\title{
HUBUNGAN TINGKAT KECEMASAN DENGAN TINGKAT KEMANDIRIAN ACTIVITIES OF DAILY LIVING PADA LANSIA
}

\author{
Tiara Sonza ${ }^{1}$, Isna Aglusi Badri' ${ }^{2}$, Roza Erda $^{3)}$ \\ Sarjana Keperawatan dan Pendidikan Profesi Ners, STIKes Mitra Bunda Persada, Jln Seraya No 1 Batam \\ Diploma III Keperawatan, STIKes Mitra Bunda Persada, Jln Seraya No 1 Batam \\ email : isna_loushe@yahoo.co.id
}

Submitted : 12-05-2020, Reviewer:15-05-2020, Accepted: 29-05-2020

\begin{abstract}
International Journal of Geriatric Psychiatry found that more than $27 \%$ of elderly people experience difficulty in carrying out daily activities due to experiencing anxiety. This study aims to determine the relationship of anxiety levels with the level of independence Activities of Daily Living in the elderly. This type of research is analytic with cross sectional design, with a population of all elderly in the Work Area of Baloi Permai Public Health Center in Batam City in 2019 with a purposive sampling technique with a sample of 66 elderly people. The results obtained from 66 elderly people, elderly who did not experience anxiety independently numbered 39 elderly (59.1\%), elderly who experienced mild anxiety with mild dependence totaling 20 elderly (30.3\%), elderly who experienced mild anxiety with dependence moderate amounted to 1 elderly $(1.5 \%)$, elderly who experienced moderate anxiety with moderate dependence amounted to 4 elderly (6.1\%), elderly who experienced severe anxiety with heavy dependence amounted to 1 elderly (1.5\%), elderly who experienced severe anxiety with a total dependence of 1 elderly (1.5\%). Hypothesis test results using kruskall wallis obtained $\rho$ value 0,000, indicating a significant relationship between the level of anxiety with the level of independence Activities of Daily Living in the elderly. Public health center can provide health education regarding the importance of checking the level of independence of the elderly and can carry out scheduled levels ofindependence during integrated healthcare center of the elderly to find out the fulfillment of daily activities in the elderly
\end{abstract}

Keywords: Anxiety, Independence, ADL, Elderly

\begin{abstract}
ABSTRAK
International Journal of Geriatric Psychiatry menemukan lebih dari $27 \%$ lansia mengalami kesulitan dalam melakukan aktivitas sehari-hari akibat mengalami kecemasan. Penelitian ini bertujuan untuk mengetahui hubungan tingkat kecemasan dengan tingkat kemandirian Activities of Daily Living pada lansia. Jenis penelitian yang digunakan adalah analitik dengan rancangan cross sectional, dengan populasi seluruh lansia di Wilayah Kerja Puskesmas Baloi Permai Kota Batam Tahun 2019 dengan teknik pengambilan sampel purposive sampling dengan jumlah sampel 66 orang lansia. Hasil penelitian didapatkan dari 66 orang lansia, lansia yang tidak mengalami kecemasan dengan mandiri berjumlah 39 lansia $(59,1 \%)$, lansia yang mengalami kecemasan ringan dengan ketergantungan ringan berjumlah 20 lansia $(30,3 \%)$, lansia yang mengalami kecemasan ringan dengan ketergantungan sedang berjumlah 1 lansia $(1,5 \%)$, lansia yang mengalami kecemasan sedang dengan ketergantungan sedang berjumlah 4 lansia $(6,1 \%)$, lansia yang mengalami kecemasan berat dengan ketergantungan berat berjumlah 1 lansia (1,5\%), lansia yang mengalami kecemasan berat dengan ketergantungan total berjumlah 1 lansia (1,5\%). Hasil uji hipotesis menggunakan kruskall wallis diperoleh $\rho$ value 0,000, menunjukkan adanya hubungan yang bermakna antara tingkat kecemasan dengan tingkat kemandirian Activities of Daily Living pada lansia. Puskesmas dapat memberikan pendidikan kesehatan mengenai pentingnya pemeriksaan tingkat kemandirian pada lansia serta dapat melakukan pemeriksaan tingkat kemandirian secara terjadwal saat Posyandu lansia untuk mengetahui pemenuhan aktivitas sehari-hari pada lansia.
\end{abstract}

Kata Kunci : Kecemasan, Kemandirian, $A D L$, Lansia 


\section{PENDAHULUAN}

Lansia atau menua adalah suatu keadaan yang terjadi di dalam kehidupan manusia. Menjadi tua merupakan proses alamiah, yang berarti seseorang telah melalui tiga tahap kehidupannya, yaitu anak, dewasa dan tua. Tiga tahap ini berbeda baik secara biologis, maupun psikologis. Memasuki usia tua berarti mengalami kemunduran, misalnya kemunduran fisik, yang ditandai dengan kulit yang mengendur, rambut memutih, gigi mulai ompong, pendengaran kurang jelas, penglihatan semakin memburuk, gerakan lambat dan figur tubuh yang tidak proporsional (Nasrullah, 2016).

Kemandirian lansia dalam kemampuan aktifitas sehari-hari didefinisikan sebagai kemandirian seseorang dalam melakukan aktivitas dan fungsi kehidupan sehari-harinya yang dilakukan oleh manusia secara rutin dan universal. Kemp dan Mitchel menyebutkan bahwa aktivitas sehari-hari pada lansia dipengaruhi oleh cemas dan depresi. Salah satu faktor yang mempengaruhi kemandirian aktivitas sehari-hari pada lansia adalah cemas (Eka, 2018). International Journal of Geriatric Psychiatry menemukan bahwa lebih dari $27 \%$ lansia mengalami kesulit an dalam melakukan aktivitas sehari-hari akibat mengalami kecemasan (Mental Health America, 2015).

Tingkat kemandirian Activities of daily living pada lansia dikaitkan dengan kecemasan karena kecemasan dapat membentuk persepsi resiko dan merangsang terjadinya rasa takut yang pada akhirnya akan membatasi tingkat aktivitas sehari- hari sehingga semakin tinggi tingkat kecemasan, maka semakin rendah Activities of daily living pada lansia, begitu juga sebaliknya semakin rendah tingkat kecemasan, maka semakin tinggi Activities of daily living pada lansia (Kurniawan, 2018).

Geriatric Mental Health Foundation menemukan bahwa kecemasan adalah masalah kesehatan mental urutan pertama pada lansia. Cemas atau anxiety merupakan suatu gangguan psikologis, dimana seseorang dengan gangguan kecemasan akan memiliki ciri seperti ketakutan atau kekhawatiran berulang, yang pada akhirnya hal tersebut dapat menyebabkan rasa takut dan hilangnya konsentrasi sehingga menyebabkan terjadinya penurunan dalam melakukan aktivitas sehari-hari. Kecemasan dipengaruhi oleh beberapa faktor, antara lain faktor internal dan eksternal. Faktor internal meliputi usia, pengalaman, aset fisik, dan faktor eksternal meliputi pengetahuan, pendidikan, finansial/material, keluarga, obat, dukungan sosial budaya (Mubarak, 2015).

Data Riskesdas (2018) menunjukkan proporsi lansia yang mengalami ketergantungan kemandirian di Indonesia sebesar 25,7\%, Kepri sebesar 2,5\%, dan Batam sebesar 6,06\%. Berdasarkan data dari Dinas Kesehatan pada tahun 2018 didapatkan tingkat kemandirian terendah terdapat pada Puskesmas Baloi Permai yaitu sebesar 11,94\% dengan jumlah lansia 7621 dan telah dilakukan studi pendahuluan pada tanggal 24 Mei dengan cara survey didapatkan sebanyak 99\% lansia dengan tingkat kemandirian $\mathrm{A}$, $0,28 \%$ lansia dengan tingkat kemandirian $\mathrm{B}$, dan $0,026 \%$ lansia dengan tingkat kemandirian $\mathrm{C}$.

Penelitian Lestari (2013) dengan judul " Hubungan Tingkat Kecemasan dengan Tingkat Kemandirian Activities of Daily Living Pada Lansia di Panti Wreda" hasil penelitian dari 84 responden didapatkan sebanyak 51 responden mengalami kecemasan dan 55 responden mengalami ketergantungan. Dari hasil analisis data dapat diambil kesimpulan bahwa terdapat hubungan yang signifikan antara tingkat kecemasan dan tingkat kemandirian pada Lansia.

Penelitian Kurniawan (2018) dengan judul " Hubungan Tingkat Kecemasan dengan Tingkat Instrumental Activities of Daily Living (IADL) Pada Lansia Dengan Hipertensi di Puskesmas Penumping " didapatkan hasil penelitian dari 54 responden didapatkan sebanyak 36 
responden mengalami kecemasan dan ketergantungan . Dari hasil analisis data dapat diambil kesimpulan bahwa terdapat Hubungan tingkat Kecemasan dengan tingkat Instrumental Activities of Daily Living (IADL) pada lansia yang mengalami hipertensi di Puskesmas Penumping.

Dampak dari kecemasan yaitu hilangnya konsentrasi akibat kekhawatiran dan rasa takut yang terjadi terus menerus sehingga menyebabkan terjadinya penurunan dalam melakukan aktivitas sehari-hari, dan mengurangi perasaan kesejahteraan pada lansia (Mental Health America, 2015).

Kecemasan dapat diatasi dengan terapi holistik. Terapi holistik adalah bentuk terapi yang tidak hanya menggunakan obat dan ditujukan hanya kepada bentuk gangguan jiwa, melainkan juga mencakup aspek-aspek lain dari pasien. Hawari mengatakan bahwa terapi penanggulangan stress, kecemasan, dan depresi dapat diberikan terapi meliputi terapi psikoterapi psikiatri, terapi keagamaan/spiritual, psikofarmaka, terapi somatik, terapi relaksasi dan terapi perilaku. Jika kecemasan sudah teratasi maka lansia tidak akan mengalami ketakutan dan kekhawatiran yang akhirnya konsentrasi lansia tidak akan hilang sehingga lansia mampu melakukan aktivitas sehari-hari (Gunawan, 2018).

Agar tetap dapat menjaga kebugaran dan dapat melakukan aktivitas sehari-hari maka lansia perlu melakukan latihan fisik seperti olahraga. Latihan aktivitas fisik sangat penting bagi lansia untuk menjaga kesehatan, mempertahankan kemampuan untuk melakukan Activities of Daily Living (ADL), dan meningkatkan kualitas kehidupan (Eka, 2018).

Tujuan dari penelitian ini adalah untuk melihat Hubungan Tingkat Kecemasan dengan Tingkat Kemandirian Activities Of Daily Living (ADL) Pada Lansia di Wilayah Kerja Puskemas Baloi Permai Kota Batam.

\section{METODE PENELITIAN}

Jenis penelitian yang digunakan adalah penelitian analitik dengan rancangan cross sectional dimana peneliti akan mengukur variabel penelitian pada saat bersamaan yaitu hubungan antara tingkat kecemasan dengan tingkat kemandirian Activities $O f$ Daily Living (ADL) pada lansia. Penelitian ini dilakukan di Wilayah Kerja Puskemas Baloi Permai Kota Batam Pada Tahun 2019.

Populasi dalam penelitian ini adalah lansia yang berada di Wilayah Kerja Puskesmas Baloi Kota Batam dan sampel dari penelitian adalah lansia yang memenuhi kriteria inklusi yaitu lansia yang berusia $\geq 60$ tahun, tinggal di Wilayah Kerja Puskesmas Baloi Permai, bisa berkomunikasi secara aktif dan tidak dengan gangguan kognitif. Teknik pengambilan sampel adalah Nonprobability sampling dengan teknik Purposive sampling yaitu penarikan sampel bukan didasarkan atas strata, random atau daerah tetapi atas tujuan tertentu sebanyak 66 orang. Instrumen dalam penelitian ini adalah menggunakan kuesioner. Untuk variabel kecemasan menggunakan Geriatric Anxiety Inventory (GAI) kuesioner yang dikembangkan oleh (Pachana, et.al, 2007) sedangkan untuk varaibel ADL menggunakan Barthel Index kuesioner yang dikembangkan sejak tahun 1965 kemudian dimodifikasi oleh grager. Teknik pengumpulan data dengan cara pengisian kuesioner dan sebelumnya lansia menandatangani Informed consent yang menyatakan bersedia menjadi responden penelitian ini..

\section{HASIL PENELITIAN}

Berdasarkan hasil penelitian mengenai Hubungan Tingkat Kecemasan Dengan Tingkat Kemandirian Activities of Daily Living Pada Lansia Di Wilayah Kerja Puskesmas Baloi Permai Kota Batam didapatkan 
Tabel 1

Distribusi Frekuensi Berdasarkan Karakteristik Lansia di Wilayah Kerja Puskesmas Baloi Permai

\begin{tabular}{|c|c|c|}
\hline Karakteristik & Frekuensi & Persentase \\
\hline \multicolumn{3}{|l|}{ Umur } \\
\hline Lansia (60-74) tahun & 64 & 96,9 \\
\hline Lansia tua (75-90) tahun & 2 & 3,0 \\
\hline \multicolumn{3}{|l|}{ Jenis Kelamin } \\
\hline Laki-laki & 20 & 30,3 \\
\hline Perempuan & 46 & 69,7 \\
\hline \multicolumn{3}{|l|}{ Pendidikan } \\
\hline SD & 54 & 81,8 \\
\hline SMP & 12 & 18,2 \\
\hline SMA & 0 & 0 \\
\hline \multicolumn{3}{|l|}{ Pekerjaan } \\
\hline Bekerja & 10 & 15,2 \\
\hline Tidak Bekerja & 56 & 84,8 \\
\hline TOTAL & 66 & 100 \\
\hline
\end{tabular}

Berdasarkan tabel diatas didapatkan bahwa lansia berusia 60-74 tahun sebanyak $64(96,9 \%)$, jenis kelamin lansia perempuan sebanyam $46 \quad(69,7 \%)$, pendidikan lansia SD sebanyak $54(81,8$ $\%)$ dan lansia yang tidak bekerja sebanyak $56(84,8 \%)$.

Tabel 2

Distribusi Tingkat Kecemasan Pada Lansia di Wilayah Kerja Puskesmas Baloi Permai Kota Batam

\begin{tabular}{|l|c|c|}
\hline \multicolumn{1}{|c|}{ Tingkat Kecemasan } & Frekuensi & Persentase \\
\hline Tidak cemas & 39 & 59,1 \\
\hline Kecemasan ringan & 21 & 31,8 \\
\hline Kecemasan sedang & 4 & 6,0 \\
\hline Kecemasan berat & 2 & 3,0 \\
\hline \multicolumn{1}{|c|}{ TOTAL } & 66 & 100 \\
\hline
\end{tabular}

Tabel 3

Distribusi Tingkat Kemandirian ADL Pada Lansia di Wilayah Kerja Puskesmas Baloi Permai Kota Batam

\begin{tabular}{|c|c|c|}
\hline $\begin{array}{c}\text { Tingkat Kemandirian } \\
\text { ADL }\end{array}$ & Frekuensi & Persentase \\
\hline Ketergantungan total & 1 & 1,5 \\
\hline Ketergantungan berat & 1 & 1,5 \\
\hline Ketergantungan sedang & 5 & 7,6 \\
\hline Ketergantungan ringan & 20 & 30,3 \\
\hline Mandiri & 39 & 59,1 \\
\hline TOTAL & 66 & 100 \\
\hline
\end{tabular}

Tabel 4

Distribusi Frekuensi Hubungan Tingkat Kecemasan dengan Tingkat Kemandirian ADL Pada Lansia di Wilayah Kerja Puskesmas Baloi Permai Kota Batam

\begin{tabular}{|c|c|c|c|c|c|c|c|c|c|c|c|c|c|}
\hline \multirow{3}{*}{ 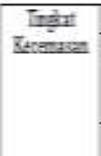 } & \multicolumn{10}{|c|}{ 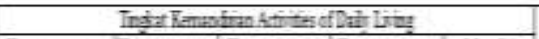 } & \multirow{2}{*}{\multicolumn{2}{|c|}{ Total }} & \multirow{3}{*}{ fatse } \\
\hline & \multicolumn{2}{|c|}{ Teteguntrong } & \multicolumn{2}{|c|}{$\begin{array}{l}\text { Teagntrge } \\
\text { Bant }\end{array}$} & \multicolumn{2}{|c|}{ Itegntrign } & \multicolumn{2}{|c|}{ Tetegnitugn } & \multicolumn{2}{|c|}{ Manfin } & & & \\
\hline & $\pi$ & 5 & $\bar{s}$ & 5 & 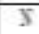 & 5 & 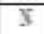 & 5 & $B$ & 5 & s & 5 & \\
\hline Tideleans & 8 & 8 & 7 & 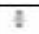 & 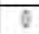 & 8 & 8 & 8 & 39 & 91 & I9 & 591 & \\
\hline $\begin{array}{l}\text { Zexemban } \\
\text { Jingen }\end{array}$ & 2 & 5 & 7 & 7 & I & 15 & $\sqrt{2}$ & 303 & 0 & 9 & II & 513 & $9 \mathrm{~cm}$ \\
\hline $\begin{array}{l}\text { Texenten } \\
\text { Sebay }\end{array}$ & I & 8 & 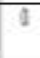 & 8 & 4 & 61 & 2 & 8 & 9 & 19 & 4 & 61 & \\
\hline$\frac{\text { Tacemtian }}{\text { Bext }}$ & 1 & 15 & 1 & 15 & 0 & 8 & 8 & 8 & 0 & 0 & 2 & 3I & \\
\hline Tital & 1 & 15 & 1 & 15 & 5 & 76 & 30 & 政3 & 39 & $\$ 1$ & 66 & 108 & \\
\hline
\end{tabular}

Berdasarkan tabel 4 menunjukkan bahwa sebagian besar lansia tidak mengalami kecemasan dengan mandiri berjumlah 39 lansia $(59,1 \%)$, hampir setengah lansia mengalami kecemasan ringan dengan ketergantungan ringan berjumlah 20 lansia $(30,3 \%)$, sebagian kecil lansia mengalami kecemasan ringan dengan ketergantungan sedang berjumlah 1 lansia (1,5\%), sebagian kecil lansia mengalami kecemasan sedang dengan ketergantungan sedang berjumlah 4 lansia $(6,1 \%)$, sebagian kecil lansia mengalami kecemasan berat dengan ketergantungan berat berjumlah 1 lansia (1,5\%), dan sebagian kecil lansia mengalami kecemasan berat dengan ketergantungan total berjumlah 1 lansia $(1,5 \%)$.

Dari hasil uji statistik kruskall wallis diperoleh bahwa nilai $\rho$ Value 0,000 maka $\mathrm{Ha}$ diterima sedangkan $\mathrm{H}_{0}$ ditolak, hal ini menunjukkan bahwa terdapat hubungan yang signifikan antara Tingkat Kecemasan dengan Tingkat Kemandirian Activities of Daily Living pada Lansia di Wilayah kerja Puskesmas Baloi Permai Kota Batam 


\section{PEMBAHASAN}

Hasil penelitian menunjukkan lansia di Wilayah Kerja Puskesmas Baloi Permai Kota Batam sebagian besar tidak mengalami kecemasan sebanyak 39 lansia $(59,1 \%)$, berdasarkan tingkat kecemasan, hampir setengah lansia mengalami kecemasan ringan sebanyak 21 lansia $(31,8 \%)$, kecemasan pada lansia disebabkan karena kesulitan tidur/istirahat, gugup/gelisah, sering gemetar, kecewa dan khawatir, sering merasa risau apabila ada masalah kecil, cemas saat beraktivitas, sering menyendiri, mudah cemas/penakut serta merasa tidak nyaman ( Lestari, 2013).

Selain itu, sebagian kecil lansia mengalami kecemasan sedang sebanyak 4 lansia (6,0\%), dan sebagian kecil lansia mengalami kecemasan berat sebanyak 2 lansia $(3,0 \%)$. Hal ini disebabkan karena karena proses penuaan sehingga lansia merasa lebih sulit dalam melakukan aktivitas sehari-hari dan meningkatkan resiko jatuh, perasaan khawatir akan penyakit yang sedang dialami lansia dan merasa cemas untuk memenuhi kebutuhan sehari-hari karena sudah tidak bekerja atau pensiun (Mubarak, 2015).

Cemas atau anxiety merupakan suatu gangguan psikologis, dimana seseorang dengan gangguan kecemasan akan memiliki ciri seperti ketakutan atau kekhawatiran berulang, yang pada akhirnya hal tersebut dapat menyebabkan rasa takut dan hilangnya konsentrasi sehingga menyebabkan terjadinya penurunan dalam melakukan aktivitas sehari-hari ( Mubarak, 2015).

Kecemasan dipengaruhi oleh beberapa faktor, antara lain faktor internal dan eksternal. Faktor internal meliputi usia, pengalaman, aset fisik, dan faktor eksternal meliputi pengetahuan, pendidikan, finansial/material, keluarga, obat, dukungan sosial budaya.

Hasil penelitian ini hampir sama dengan Penelitian Lestari (2013) dengan judul " Hubungan Tingkat Kecemasan dengan Tingkat Kemandirian Activities of
Daily Living Pada Lansia di Panti Wreda" hasil penelitian menunjukkan dari 84 lansia didapatkan mayoritas lansia tidak mengalami cemas yaitu sebanyak 33 lansia, dan sisanya 23 lansia mengalami cemas ringan, 15 lansia mengalami cemas sedang, dan 13 lansia mengalami cemas berat.

Berdasarkan hasil penelitian dapat disimpulkan bahwa pada usia lanjut, manusia akan lebih cenderung mengalami kecemasan. Hal ini bisa disebabkan karena tingginya jumlah lansia yang sudah tidak bekerja sehingga lansia cendrung merasa cemas untuk dapat memenuhi kebutuhan sehari-harinya, dan sebagian besar lansia berjenis kelamin perempuan yang mana kecemasan lebih rentan menyerang perempuan sesuai dengan pendapat beberapa ahli yang menyebutkan bahwa laki-laki memiliki tingkat kecemasan lebih rendah dibandingkan perempuan. Myers dalam Annisa (2008), menyebutkan bahwa perempuan lebih cemas akan ketidakmampuannya dibanding dengan laki-laki, laki-laki lebih aktif, eksploratif, sedangkan perempuan lebih sensitif (Mubarak, 2015).

Hasil penelitian menunjukkan dari 66 lansia yang diteliti, berdasarkan kategori tingkat kemandirian diperoleh hasil bahwa sebagian besar lansia masih mandiri yaitu sebanyak 39 lansia $(59,15)$, hampir setengah lansia mengalami ketergantungan ringan sebanyak 20 lansia $(30,3 \%)$ dengan tanda-tanda mandiri pada semua fungsi, kecuali mandi dan satu fungsi lainnya, dan sebagian kecil lansia mengalami ketergantungan sedang sebanyak 5 lansia $(7,6 \%)$ dengan tanda-tanda mandiri pada semua fungsi, kecuali mandi, berpakaian, pergi ke toilet, dan satu fungsi lainnya. Sebagian besar lansia mengalami ketergantungan ringan dan sedang karena secara fisik kondisi sudah menurun, kaki gemetaran saat berjalan, tetapi masih mampu melakukannya meskipun lambat dan terkadang membutuhkan bantuan dari teman atau keluarga, juga karena adanya penyakit yang diderita lansia.

Berdasarkan hasil penelitian sebagian kecil lansia mengalami ketergantungan 
berat sebanyak 1 lansia $(1,5 \%)$ dengan tanda-tanda mandiri pada semua fungsi, kecuali mandi, berpakaian, pergi ke toilet, berpindah dan satu fungsi lainnya, dan sebagian kecil lansia mengalami ketergantungan total sebanyak 1 lansia (1,5\%) dengan tanda-tanda ketergantungan pada semua fungsi. Sebagian besar lansia mengalami ketergantungan berat dan total disebabkan karena kondisi fisik yang menurun, usia yang semakin tua, kaki gemetaran saat berjalan, kaki lemah sudah tidak mampu dibuat berjalan sehingga sulit untuk melakukan aktivitas sehari-hari, serta adanya penyakit yang diderita lansia.

Kemandirian lansia dalam kemampuan aktifitas sehari-hari didefinisikan sebagai kemandirian seseorang dalam melakukan aktivitas dan fungsi kehidupan sehari-harinya yang dilakukan oleh manusia secara rutin dan universal. Salah satu faktor yang mempengaruhi kemandirian aktivitas sehari-hari pada lansia adalah cemas (Eka, 2018).

Hasil penelitian ini juga hampir sama dengan Penelitian Kusuma (2018) dengan judul " Hubungan Tingkat Kecemasan Terhadap Aktivitas Sehari-hari Pada Lansia di Panti Werdha Wana Seraya " didapatkan hasil penelitian dari 40 lansia didapatkan sebanyak 35 lansia mandiri dan 5 lansia mengalami ketergantungan.

Berdasarkan hasil penelitian dapat disimpulkan bahwa penyebab ketergantungan pada lansia dipengaruhi oleh jenis kelamin, dapat dilihat dari jenis kelamin lansia sebagian besar lansia berjenis kelamin perempuan. Diketahui bahwa lansia dengan jenis kelamin perempuan memiliki tingkat kemandirian Activities of Daily Living lebih rendah yang disebabkan karena lansia berjenis kelamin perempuan banyak mengalami kelemahan dan disabilitas sehingga mempengaruhi kemandirian Activities of Daily Living. Berbeda dengan lansia berjenis kelamin laki-laki yang memiliki tingkat kemandirian Activities of Daily Living lebih tinggi, hal ini disebabkan karena lansia berjenis kelamin laki-laki cenderung mempunyai kekuatan fisik lebih baik dibandingkan dengan perempuan. Menurut Watson (2010) lansia dengan jenis kelamin laki-laki memiliki tingkat kemandirian yang lebih tinggi jika dibandingkan dengan lansia berjenis kelamin perempuan. Hal tersebut sesuai dengan penelitian yang dilakukan oleh Kurniawan (2018) bahwa berdasarkan hasil analisa jenis kelamin terhadap tingkat kemandirian menunjukkan bahwa lansia lansia laki-laki memiliki tingkat kemandirian yang lebih tinggi jika dibandingkan dengan lansia lansia perempuan.

Berdasarkan hasil penelitian menunjukkan bahwa dari 66 orang lansia, sebagian besar lansia tidak mengalami kecemasan dengan mandiri berjumlah 39 lansia $(59,1 \%)$, hampir setengah lansia mengalami kecemasan ringan dengan ketergantungan ringan berjumlah 20 lansia (30,3\%), sebagian kecil lansia mengalami kecemasan ringan dengan ketergantungan sedang berjumlah 1 lansia (1,5\%), sebagian kecil lansia mengalami kecemasan sedang dengan ketergantungan sedang berjumlah 4 lansia $(6,1 \%)$, sebagian kecil lansia mengalami kecemasan berat dengan ketergantungan berat berjumlah 1 lansia $(1,5 \%)$, dan sebagian kecil lansia mengalami kecemasan berat dengan ketergantungan total berjumlah 1 lansia $(1,5 \%)$.

Berdasarkan hasil uji statistik kruskall wallis diperoleh bahwa nilai $\rho$ Value 0,000 maka $\mathrm{Ha}$ diterima sedangkan $\mathrm{H}_{0}$ ditolak, hal ini menunjukkan bahwa terdapat hubungan yang signifikan antara Tingkat Kecemasan dengan Tingkat Kemandirian Activities of Daily Living pada Lansia di Wilayah kerja Puskesmas Baloi Permai Kota Batam Tahun 2019.

Tingkat kemandirian Activities of daily living pada lansia dikaitkan dengan kecemasan karena kecemasan dapat membentuk persepsi resiko dan merangsang terjadinya rasa takut dan khawatir yang pada akhirnya akan mempengaruhi konsentrasi lansia dan membatasi tingkat aktivitas sehari- hari sehingga semakin tinggi tingkat kecemasan, maka semakin rendah 
Activities of daily living pada lansia, begitu juga sebaliknya semakin rendah tingkat kecemasan, maka semakin tinggi Activities of daily living pada lansia (Kurniawan, 2018).

Hasil penelitian ini hampir sama dengan Penelitian Lestari (2013) dengan judul " Hubungan Tingkat Kecemasan dengan Tingkat Kemandirian Activities of Daily Living Pada Lansia di Panti Wreda" dengan rancangan cross sectional didapatkan hasil nilai p-value $0,00<\alpha 0,05$ dengan demikian uji hipotesis menyatakan bahwa terdapat hubungan antara tingkat kecemasan dengan Tingkat Kemandirian Activities of Daily Living Pada Lansia.

Hasil penelitian ini juga hampir sama dengan Penelitian Kurniawan (2018) dengan judul " Hubungan Tingkat Kecemasan dengan Tingkat Instrumental Activities of Daily Living (IADL) Pada Lansia Dengan Hipertensi di Puskesmas Penumping " dengan rancangan cross sectional didapatkan hasil nilai p-value $0,001<\alpha 0,05$ dengan demikian uji hipotesis menyatakan bahwa terdapat hubungan antara tingkat kecemasan dengan tingkat kemandirian Instrumental Activities of Daily Living (IADL) Pada Lansia.

Berdasarkan data di atas dapat disimpulkan bahwa semakin tinggi tingkat kecemasan, maka semakin rendah Activities of daily living pada lansia, begitu juga sebaliknya semakin rendah tingkat kecemasan, maka semakin tinggi Activities of daily living pada lansia. Dari penelitian ini dapat diketahui bahwa jenis kelamin dapat mempengaruhi tingkat kecemasan dan tingkat kemandirian Activities of daily living. Hal tersebut sebagaimana ditunjukkan dalam penelitian Kurniawan (2018) yang menyimpulkan bahwa faktor yang mempengaruhi kecemasan dan kemampuan Activities of daily living pada lansia antara lain faktor jenis kelamin.

\section{SIMPULAN}

Hasil penelitian menunjukan dari hasil uji statistik kruskall wallis diperoleh bahwa nilai $\rho=0,000$ maka Ha diterima sedangkan $\mathrm{H}_{0}$ ditolak, hal ini menunjukkan bahwa terdapat hubungan yang signifikan antara Tingkat Kecemasan dengan Tingkat Kemandirian Activities of Daily Living pada Lansia di Wilayah kerja Puskesmas Baloi Permai Kota Batam

\section{REFERENSI}

Aini, N. (2018). Teori Model Keperawatan Beserta Aplikasinya Dalam Keperawatan. Malang: Universitas Muhammadiyah.

Dinas Kesehatan Kota Batam. (2018).

Dwiastuti, R. (2017). Metode Penelitian Sosial Ekonomi Pertanian Dilengkapi Pengenalan Berbagai Perspektif Pendekatan Metode Penelitian. UB Press.

Ekasari, M., Riasmini, N., Hartini, T. (2018). Meningkatkan Kualitas Hidup Lansia Konsep Dan Berbagai Intervensi. Wineka Media.

Fathnur, S. (2018). Metodelogi Penelitian Farmasi Komunitas dan Eksperimental. Edisi ke-1. Yogyakarta: Deepublish.

Fitrah, M., \& Luthfiyah. (2017). Metodelogi Penelitian Penelitian Kualitatif, Tindakan Kelas, \& Studi Kasus. Sukabumi: CV Jejak.

Gunawan, F. (2018). Senarai Penelitian Pendidikan, Hukum, Dan Ekonomi Di Sulawesi Tenggara. Yogyakarta: Deepublish.

Kementrian Kesehatan Republik Indonesia. (2017).

Kurniawan, A. (2018). Hubungan Tingkat Kecemasan dengan Tingkat Instrumental Activities of Daily Living (IADL) Pada Lansia Dengan Hipertensi di Puskesmas Penumping. Jurnal. Surakarta: Fakultas Ilmu Kesehatan Universitas Muhammadiyah.

Kusuma, I., Ardani, I. (2018). Hubungan Tingkat Kecemasan Terhadap Aktivitas Sehari-hari Pada Lansia di Panti Werdha Wana Seraya. Jurnal. Denpasar: Fakultas kedokteran Universitas Udayana. 
ISSN:2528-66510;Volume 5;No.3(Juny, 2020): 688-695 Jurnal Human Care

Lestari, R., Wihastuti, T., Rahayu, B. (2013). Hubungan Tingkat Kecemasan dengan Tingkat Kemandirian Activities of Daily Living Pada Lansia di Panti Wreda. Jurnal. Malang: Fakultas Kedokteran Universitas Brawijaya.

Mental Health America. (2015). Anxiety In Older Adults.

Mubarak, W., Indrawati, L., Susanto, J. (2015). Buku Ajar Ilmu Keperawatan dasar. Edisi Ke-2. Salemba Medika.

Muhith, A., \& Siyoto, S. (2016). Pendidikan Keperawatan Gerontik. Edisi ke-1. Yogyakarta: Andi.

Nasrullah, D. (2016). Buku Ajar Ilmu Keperawatan Gerontik Dengan Pendekatan Asuhan Keperawatan Nanda Nic Noc. Jilid 1. Jakarta: Salemba Medika.

Ninit, A. (2018). Buku Ajar Metode Penelitian Pengajaran Bahasa Indonesia. Yogyakarta: Deepublish.
Pieter, H. (2017). Dasar Dasar Komunikasi Bagi Perawat. Edisi ke-1. Jakarta: Prenada Media Group.

Pradana, S. (2017). Pengaruh Senam Tera Terhadap Penurunan Tingkat Kecemasan Pada Lansia Di Panti Tresna Werdha Hargo Dedali. Skripsi. Surabaya: Fakultas Keperawatan Universitas Airlangga.

Profil Dinas Kesehatan Kota Batam. (2017).

Riset Kesehatan Dasar. (2018).

Sarmanu. (2017). Dasar Metodelogi Penelitian Kuantitatif, Kualitatif, dan Statistika. Surabaya: Universitas Airlangga.

Setyawati, V., \& Hartini, E. (2018). Buku Ajar Dasar Ilmu Gizi Kesehatan Masyarakat. Edisi ke-1. Yogyakarta: Deepublish.

Sunaryo, dkk. (2015). Asuhan Keperawatan Gerontik. Yogyakarta: Andi. 